University of Nebraska - Lincoln

DigitalCommons@University of Nebraska - Lincoln

Papers in the Earth and Atmospheric Sciences

Earth and Atmospheric Sciences, Department

March 2007

\title{
Lacustrine evidence for moisture changes in the Nebraska Sand Hills during Marine Isotope Stage 3
}

Kimberly C. Jacobs

University of Nebraska-Lincoln

Sherilyn C. Fritz

University of Nebraska-Lincoln, sfritz2@unl.edu

James B. Swinehart

University of Nebraska-Lincoln, jswinehart1@unl.edu

Follow this and additional works at: https://digitalcommons.unl.edu/geosciencefacpub

Part of the Earth Sciences Commons

Jacobs, Kimberly C.; Fritz, Sherilyn C.; and Swinehart, James B., "Lacustrine evidence for moisture changes in the Nebraska Sand Hills during Marine Isotope Stage 3" (2007). Papers in the Earth and Atmospheric Sciences. 8.

https://digitalcommons.unl.edu/geosciencefacpub/8

This Article is brought to you for free and open access by the Earth and Atmospheric Sciences, Department of at DigitalCommons@University of Nebraska - Lincoln. It has been accepted for inclusion in Papers in the Earth and Atmospheric Sciences by an authorized administrator of DigitalCommons@University of Nebraska - Lincoln. 
Published in Quaternary Research 67:2 (March 2007), pp. 246-254; doi:10.1016/j.yqres.2006.12.001

Copyright (C) 2006 University of Washington; published by Elsevier Inc. Used by permission.

http://www.sciencedirect.com/science/journal/00335894

Submitted April 19, 2006; published online February 1, 2007.

\title{
Lacustrine evidence for moisture changes in the Nebraska Sand Hills during Marine Isotope Stage 3
}

\author{
Kimberly C. Jacobs ${ }^{\mathrm{a}}$, Sherilyn C. Fritz ${ }^{\mathrm{a}, \mathrm{b}, *}$, and James B. Swinehart ${ }^{\mathrm{a}, \mathrm{c}}$ \\ ${ }^{\mathrm{a}}$ Department of Geosciences, ${ }^{\mathrm{b}}$ School of Biological Sciences, and ${ }^{\mathrm{c}}$ School of Natural Resources, \\ University of Nebraska-Lincoln, Lincoln, NE 68588, USA \\ * Corresponding author-S. C. Fritz, emailsfritz2@unl.edu
}

\begin{abstract}
In the central Great Plains of North America, loess stratigraphy suggests that climate during the late Pleistocene was cold and dry. However, this record is discontinuous, and there are few other records of late-Pleistocene conditions. Cobb Basin, located on the northern edge of the Nebraska Sand Hills, contains lacustrine sediments deposited during Marine Isotope Stage 3, beginning approximately $45,000 \mathrm{cal} \mathrm{yr} \mathrm{BP}$ and continuing for at least 10,000 yr. The lake was formed by a dune dam blockage on the ancient Niobrara River, and its deposits contain a diatom record that indicates changes through time in lake depth driven by changes in effective moisture. During the earliest stages of lake formation, the climate was arid enough to mobilize dunes and emplace dune sand into a blocking position within the Niobrara streambed. Diatom assemblages suggest that lake-level was shallow at formation, increased substantially during a wet interval, and then became shallow again, as arid conditions resumed. By about 27,000 cal yr BP the lake was filled, and a shallow ephemeral river occupied the basin.
\end{abstract}

Keywords: Pleistocene, Central Great Plains, paleoclimate, paleolake, paleolimnology, diatoms, dune dam

\section{Introduction}

Ice and marine cores from the North Atlantic region indicate that late Pleistocene climate was dynamic, as manifested in the Dansgaard-Oeschger (D-O) cycles (Dansgaard et al., 1993 and Bond et al., 1993) of abrupt warming followed by a slow cooling trend that ultimately terminated in Heinrich events, large discharges of icebergs from the Laurentide Ice Sheet into the North Atlantic. During this time, various lobes of the Laurentide Ice Sheet advanced and retreated across the northern Great Plains (Dyke and Prest, 1987). Immediately to the south, in the central Great Plains, relatively little is known about late Pleistocene environments.

Most of what is known about the late Pleistocene in the central Great Plains is from loess sequences (Bettis et al., 2003), composed of wind-blown sediment derived mainly from non-glaciated landscapes to the northwest of the loess deposits (Alkeinikoff et al., 1998 and Mason, 2001). The high rates of erosion and transport indicate strong winds and cold dry conditions (Bettis et al., 2003). Three major Pleistocene loess units exist in Nebraska. From oldest to youngest, these are Loveland Loess, Gilman Canyon Formation (equivalent to Pisgah Formation in Iowa), and Peoria Loess. Thermoluminescence (TL) dating of the Loveland Loess suggests it accumulated during the penultimate glacial period, equivalent to Marine Isotope Stage (MIS) 6 (Forman et al., 1992, Maat and Johnson, 1996 and Forman and Pierson, 2002). The Sangamon Soil developed in the upper part of the Loveland Loess and represents the majority of the Sangamon interglacial (MIS5) until deposition of the Gilman Canyon Formation. Optically stimulated luminescence (OSL) dating of the loess and ${ }^{14} \mathrm{C}$ dating of the overlying soil organic matter suggest that the Gilman Canyon Formation accumulated sometime between $\sim 45,000$ and 25,000 cal yr BP (Forman et al., 1992, Maat and Johnson, 1996, Muhs et al., 1999 and Forman and Pierson, 2002). In southeastern Nebraska, $\delta^{13} \mathrm{C}$ values within 


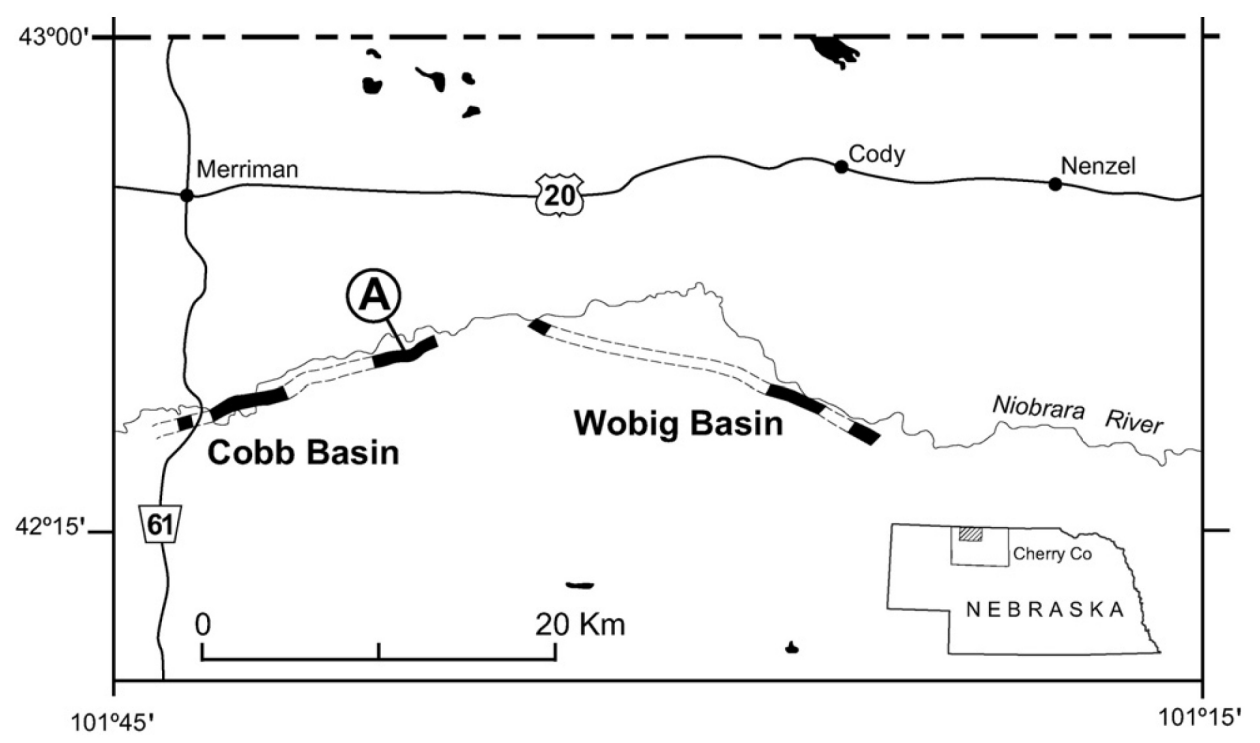

Figure 1. Map showing the location of the Cobb and Wobig basins and their proposed extent based on outcrop exposures (darkened units). The core location is marked "A".

a Gilman Canyon Formation soil (38,000-30,000 cal yr BP) are interpreted as a product of a $\mathrm{C} 4$ dominated grassland, with July temperatures at least as warm as today (Johnson et al., in press). This interpretation is consistent with the grassland-sage steppe community inferred between 34,000 and 29,000 cal yr BP from a pollen record from the Cheyenne bottoms in central Kansas (Fredlund, 1955). Peoria Loess overlies the Gilman Canyon Formation. TL and ${ }^{14} \mathrm{C}$ ages on the Peoria Loess indicate that it began to accumulate around 23,000 cal yr BP and that deposition continued until about $12,000 \mathrm{cal}$ yr BP (Maat and Johnson, 1996 and Roberts et al., 2003).
On the northern edge of the Nebraska Sand Hills, the Niobrara River has exposed late Pleistocene lacustrine and alluvial sediments in two basins: the eastern Wobig Basin and western Cobb Basin (Figure 1). The lake deposits most likely formed from dune dam blockages on the ancient Niobrara River (Loope et al., 1995, Swinehart et al., 1996 and Muhs et al., 2000), creating a lake setting similar to a reservoir. Cobb Basin, located in Cherry County, Nebraska contains a thick sedimentary fill (Figure 2). These sediments provide the potential of a continuous sequence for reconstructing the nature of the environment over the period of their deposition. In this

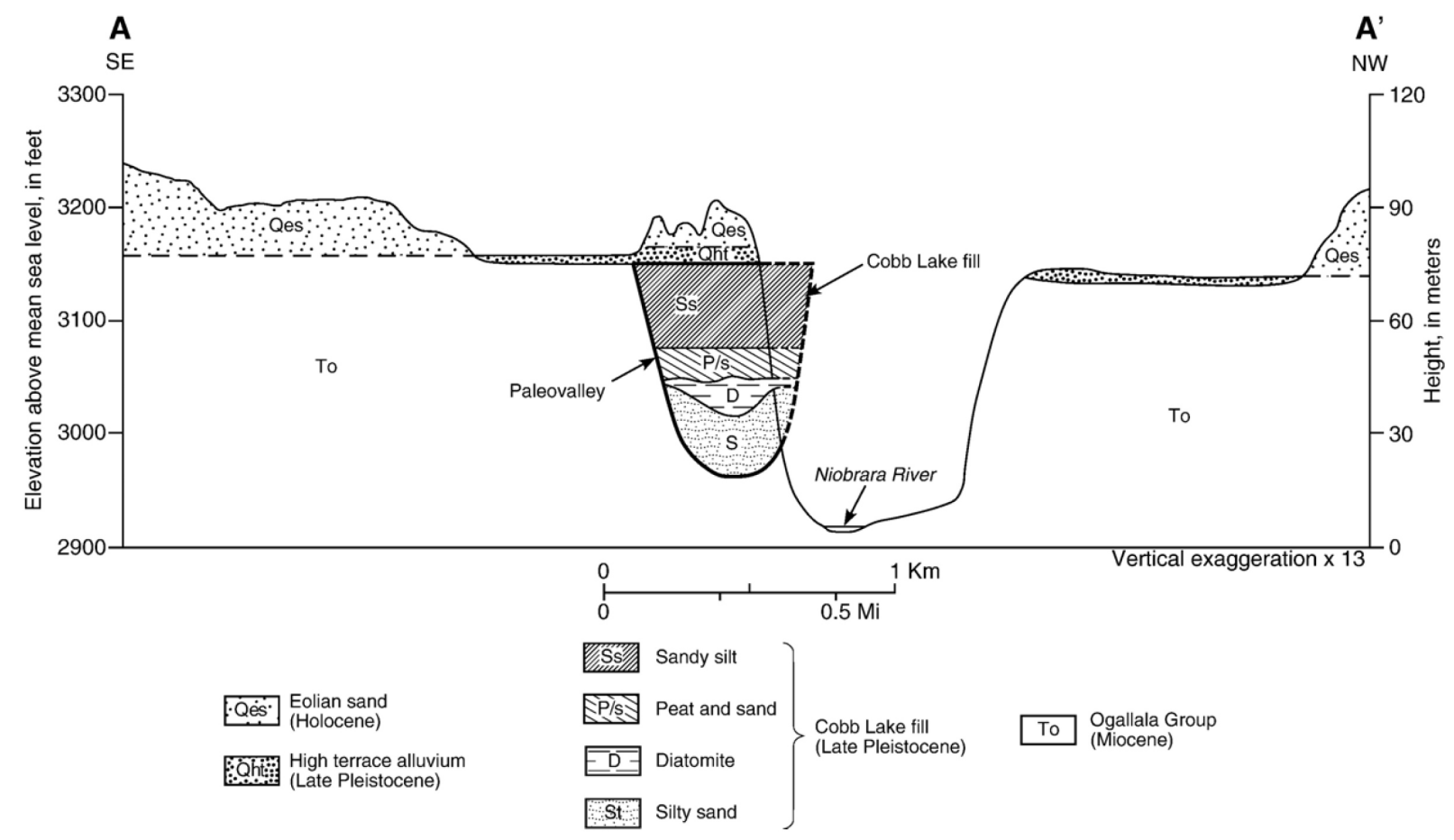

Figure 2. Cross-section through the Cobb Basin units relative to the current Niobrara River. 
study, diatoms preserved in Cobb Basin sediments are used to develop a paleoecological and paleoclimatic reconstruction for the late Pleistocene in the central Great Plains region.

\section{Site description}

Cobb Basin is located along the Niobrara River on the northern edge of the Nebraska Sand Hills (Figure 1). It ranges from 0.5 to $1 \mathrm{~km}$ wide and is about $20 \mathrm{~km}$ in length. It is essentially an ancient reservoir of an ancestral Niobrara River. The basin has a maximum depth of approximately $55 \mathrm{~m}$ and becomes shallow to the southwest. The Cobb Basin sediments incise into the Ogallala Group (Miocene) and are covered by alluvial sediments informally called the Connely Flat beds (Larson, 2001), which are overlain by eolian sand (Figure 2).

The Connely Flat beds are restricted to the Niobrara River basin in north-central Nebraska and contain a fauna with boreal affinities. Radiocarbon dates on gastropods and a paleosol place the age of this unit between 27,000 and 10,000 cal yr BP. The unit contains cross-bedded, medium-grained sand with lenses of poorly sorted gravel to very coarse pebbly sand and represents a bedload-dominated drainage, with a course similar to that of the modern Niobrara River. However, the river at this time was not entrenched but was wide and shallow, with ephemeral flow (Larson, 2001).

Above the Connely Flat beds lies eolian sand of the Nebraska Sand Hills. Presently, the dunes are stabilized by vegetation; however, the dunes have been reactivated by episodes of severe drought several times in the past $18,000 \mathrm{yr}$ (Loope and Swinehart, 2000, Goble et al., 2004 and Mason et $a l ., 2004)$ and presumably earlier, as well. Although the timing of the origin of the dune field is controversial, most recent studies indicate that the extant dunes formed during the lateGlacial period and Holocene (Loope and Swinehart, 2000 and Goble et al., 2004).

\section{Regional climate}

The Nebraska Sand Hills currently receive an average annual total of $58 \mathrm{~cm}$ of precipitation in the east and $43 \mathrm{~cm}$ in the west. The majority of precipitation falls in spring and summer, primarily as a result of monsoonal flow from the Gulf of Mexico. Winter precipitation, usually snow, is generally associated with cold polar air masses (Wilhite and Hubbard, 1998).

Average annual temperatures in the Sand Hills are about $9^{\circ} \mathrm{C}$, with mean summer (JJA) temperatures of $\sim 21^{\circ} \mathrm{C}$ and average winter (October-March) temperatures of approximately $0^{\circ} \mathrm{C}$ (Wilhite and Hubbard, 1998).

\section{Methods}

Core 24-A-02 was obtained with a hollow stem auger and drilled by the Conservation and Survey Division, University of Nebraska-Lincoln at approximately SW1/4, SE1/4, Section $10, \mathrm{~T} 33 \mathrm{~N}, \mathrm{R} 36 \mathrm{~W} ; 42^{\circ} 50^{\prime} 47^{\prime \prime} \mathrm{N}, 101^{\circ} 32^{\prime} 31^{\prime \prime} \mathrm{W}$. The core penetrated through the thickest part of Cobb Basin to a recoverable depth of $34 \mathrm{~m}$. The sedimentology of the core was described, and sediment samples for diatom analysis were extracted from organic/clay-rich layers of the upper sandy silt facies, the peat and sand facies, and the top section of the diatomite facies (Figure 3).

In July 2003, additional sediment samples were collected in the field from the diatomite facies $\left(42^{\circ} 59^{\prime} 43^{\prime \prime} \mathrm{N}\right.$, $101^{\circ} 32^{\prime} 38^{\prime \prime} \mathrm{W}$ ). A large portion of overburden was removed to expose a fresh face, which was sampled at 4-cm intervals over a thickness of approximately $8 \mathrm{~m}$.

Sediment samples were prepared for diatom analysis by dissolving carbonate in $10 \% \mathrm{HCl}$ and organic material in cold $30 \%$ hydrogen peroxide. The cleaned and rinsed samples were then mounted on glass microscope slides with Zrax mounting medium. Approximately 300 diatom valves were identified and counted on each slide with a $100 \times / 1.4$ N.A. oil-immersion objective, using differential interference contrast on a Carl Zeiss Axioskop 2 microscope. Diatom species percentage data versus stratigraphic depth were plotted using the $\mathrm{C} 2$ data analysis program, version 1.3 (Juggins, 2003). Diatom zones were

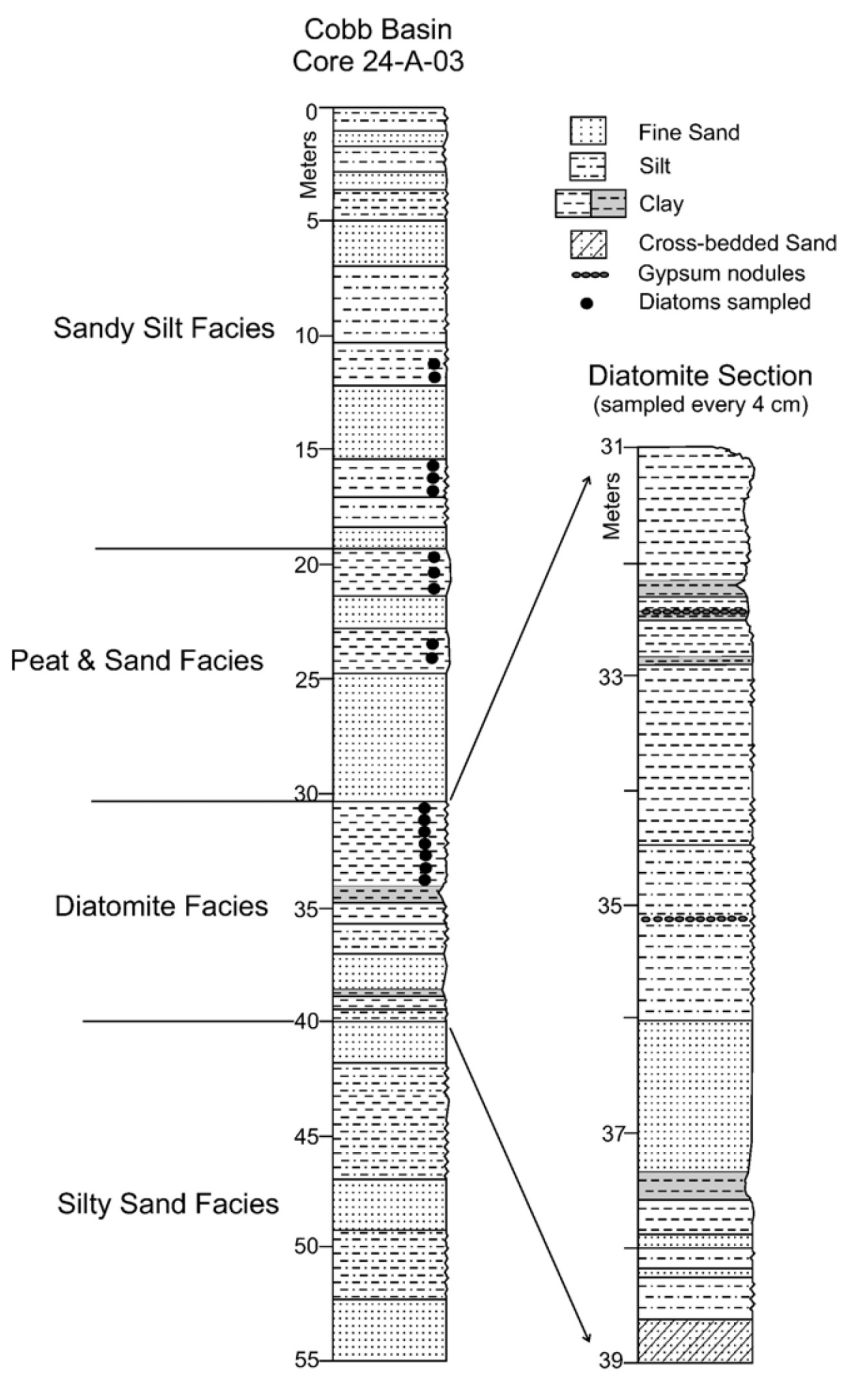

Figure 3. Detailed stratigraphic column for the Cobb Basin section. Depths are in meters. 


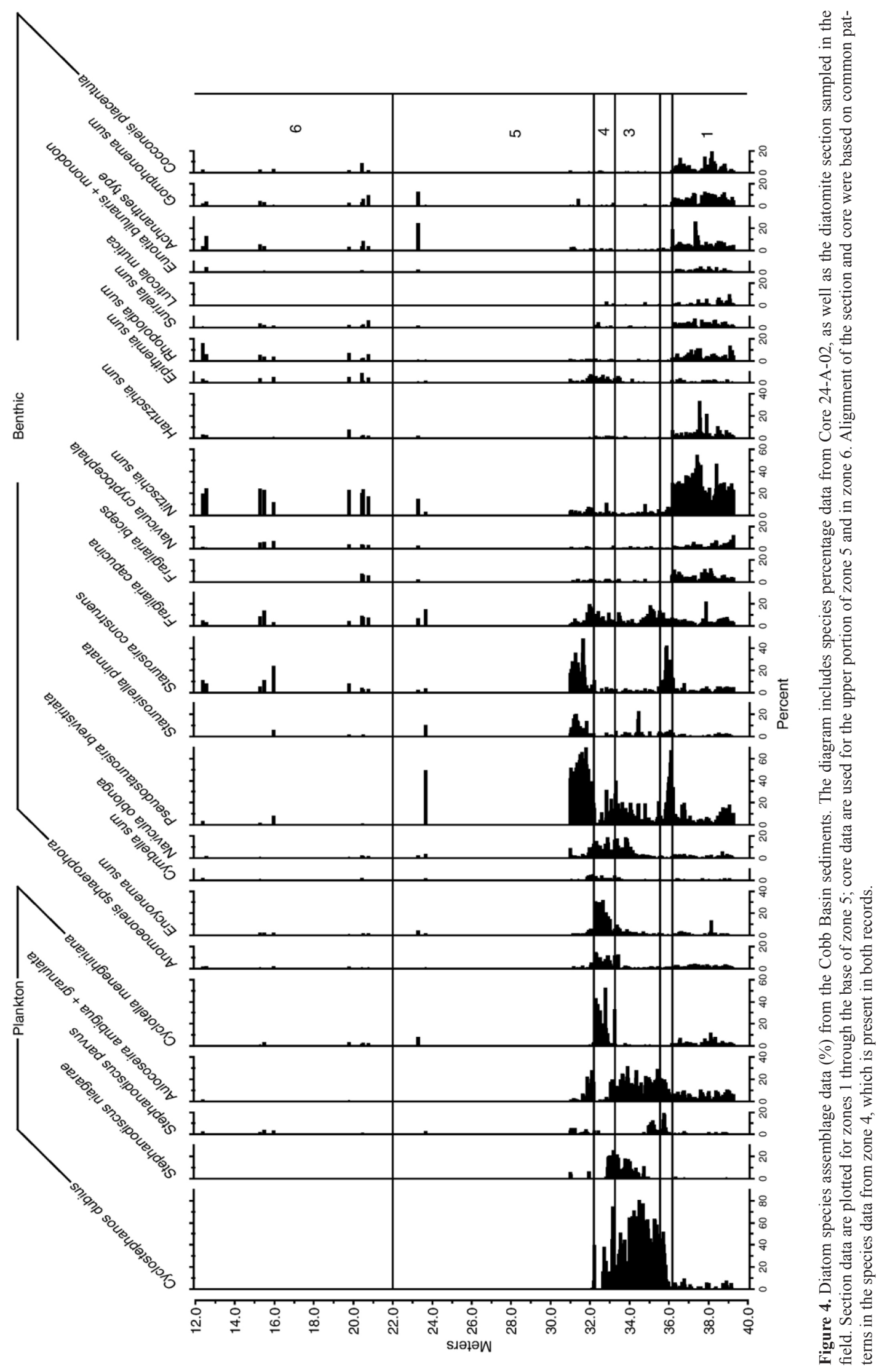


Table 1.

Radiocarbon dates obtained from the Cobb and Wobig Basins

\begin{tabular}{|c|c|c|c|c|c|}
\hline Lab no. & ID number & Material dated & Locality & $\begin{array}{l}\text { Radiocarbon age } \\
\left({ }^{14} \mathrm{C} \text { yr BP }\right)\end{array}$ & $\begin{array}{l}\text { Calendar age } \\
\text { (cal yr BP) }\end{array}$ \\
\hline Beta- 84702 & RCJ95-2 & $\begin{array}{l}\text { Carbonized plant fragments } \\
\text { (leaf and leaf stems) }\end{array}$ & Wobig Basin & $38,420 \pm 660$ & $40,848 \pm 391$ \\
\hline Beta- 88936 & RCJ95-5 & $\begin{array}{l}\text { Charcoal fragments } \\
\text { from diatomaceous peat }\end{array}$ & Cobb Basin & $41,790 \pm 900$ & $42,934 \pm 977$ \\
\hline Beta-95358 & RCJ96-4 & Diatomaceous peat & Cobb Basin & $35,130 \pm 1150$ & $38,535 \pm 1160$ \\
\hline \multirow[t]{2}{*}{ Beta-95359 } & RCJ96-5 & Wood charcoal & Cobb Basin & $32,150 \pm 210$ & $35,375 \pm 492$ \\
\hline & TX-9132 & Diatomaceous peat & Cobb Basin & $38,740 \pm 1470$ & $42,217 \pm 839$ \\
\hline CAMS-42815 & RCJ97-6 & Wood & Cobb Basin & $41,440 \pm 870$ & $42,679 \pm 908$ \\
\hline CAMS-42816 & RCJ97-5 & Wood & Cobb Basin & $45,500 \pm 1500$ & $45,708 \pm 1578$ \\
\hline
\end{tabular}

Calendar age conversions were generated by the CalPal Online Radiocarbon Calibration program: http://www.calpal-online.de/

defined based on visual examination of patterns in the species data. Zones represented in both the core and diatomite section were correlated to join the two records into one unified stratigraphic record (Figure 4).

Seven AMS radiocarbon dates were obtained from charcoal, wood, peat, and carbonized plant fragments found within the Cobb and Wobig basins (Table 1). All of the Cobb Basin dates, except for RCJ97-6 and RCJ97-5, were collected within the diatomite facies (Figure 5).

\section{Results}

\section{Dating}

The calibrated radiocarbon ages on the Cobb Basin sediments range from 45,700 to 35,400 cal yr BP (Table 1, Figure $5)$. The ages are not in chronological order relative to elevation in the section, and thus the dates provide only a very general constraint on the age of the unit. The most reliable dates are considered to be 41,440 and $45,500{ }^{14} \mathrm{C}$ yr BP (RCJ976 and RCJ97-5), which were obtained from the western end of the basin, about $11 \mathrm{~km}$ west of core 24-A-02. These wood samples were well preserved in reduced, green, silty mud that showed no signs of oxidation. These dates are interpreted to be stratigraphically below the thick diatomite unit analyzed in this study. The correlation of these ages with the analyzed unit is based on elevation with the lake basin (Figure 5); the elevation of the $41,000{ }^{14} \mathrm{C}$ yr BP sample is $919 \mathrm{~m}(3,015 \mathrm{ft})$, which is equivalent to the elevation of the base of the studied diatomite. The elevation of the older sample is $912 \mathrm{~m}(2,990 \mathrm{ft})$ (Figure 5).

\section{Stratigraphy}

Four major facies units comprise the eastern Cobb Basin fill (Figure 3): a basal silty sand facies, a diatomite facies, a peat and sand facies, and an upper sandy silt facies. The basal silty sand facies contains well-sorted, medium to fine laminated sand and silt, with occasional ripple lamination. The diatomite facies is mostly laminated diatomite, with interbedded units of silt and well-sorted fine sand. Gastropods, fish fragments, and occasional gypsum beds of diagenetic origin occur in this facies. The peat and sand facies contains interbedded units of laminated peaty silt and sandy silt. Thin diatomaceous lenses also exist in this facies, but none are as exten-

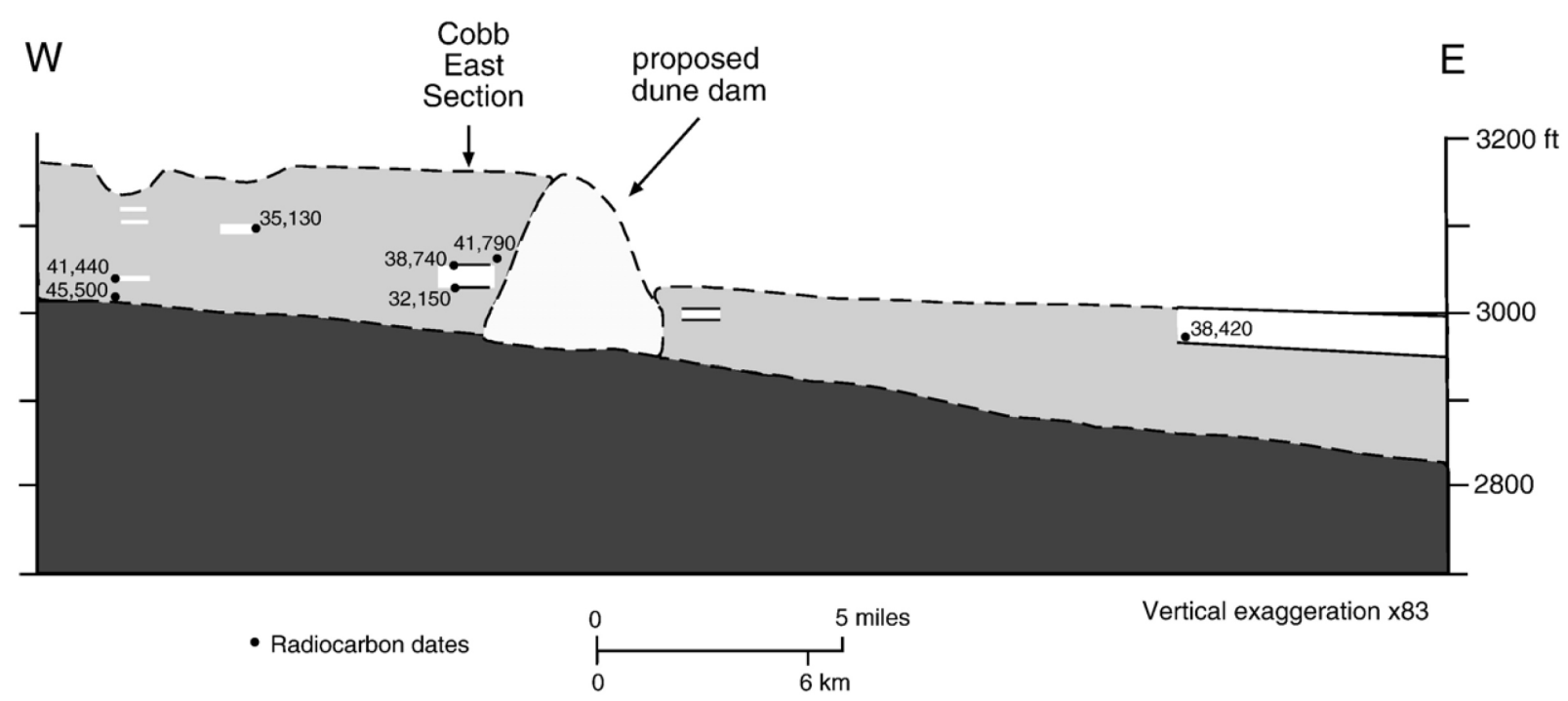

Figure 5. Morphometry of the Cobb Lake basin and the approximate stratigraphic locations of the radiocarbon samples. Elevations are from the USGS topographic map. White sections represent diatomite exposures. Ages are in ${ }^{14} \mathrm{C}$ yr BP. 
sive as the underlying diatomite facies. The uppermost sandy silt facies is very similar in composition to the basal silty sand facies, with massive and laminated sandy silt and occasional cross-bedding and ripple lamination. Generally, these two facies units contain the coarsest sediment. The upper $10 \mathrm{~m}$ of the sandy silt facies also contains a small amount of eolian input in the form of loess.

\section{Diatoms}

The diatom composition of the Cobb Basin fill is used to reconstruct changes in lake depth through time. Diatom species assemblages from Core 24-A-02 and the sampled diatomite outcrop are plotted in Figure 4. Shaded areas represent sections of the core that were not sampled. Zone 1 is dominated by benthic species, including epipelic (grows on mud) taxa in the genera Nitzschia, Hantzschia, Eunotia, and Surirella, as well as epiphytic (grows on macrophytes/aquatic plants) forms, such as Gomphonema, Cocconeis, Rhopolodia, and Achnanthes. Planktonic diatoms occur in low relative abundance. Aulacoseira granulata is the most abundant tychoplanktonic variety and indicates shallow nutrient-rich waters (Stoermer and Yang, 1969). Zone 2 is a transitional zone between the shallow zone 1 and a deeper zone 3. It is dominated by Pseudostaurosira brevistriata and Staurosira construens. Planktonic taxa, such as Cyclostephanos dubius, and tychoplanktonic species in the genus Aulacoseira increase in relative abundance up-section. Zone 3 is dominated by planktonic taxa, including Cyclostephanos dubius, Stephanodiscus parvus, and Stephanodiscus niagarae, as well as the tychoplanktonic species Aulacoseira ambigua and A. granulata. This combination of species indicates that this zone represents the deepest phase of Paleolake Cobb and that the lake was nutrient-rich. Benthic species are consistently low in numbers or absent.

The species composition of the upper part of the Cobb Basin sequence (zones 4,5 , and 6) suggests a gradual decrease in lake depth through time. Zone 4 shows a marked increase in the planktonic Cyclotella meneghiniana, a species that is widespread in moderately shallow lakes from freshwater to saline (Fritz et al., 1993). Benthic diatoms, particularly Anomoeoneis sphaerophora, Encyonema spp., Cymbella spp., and Navicula oblonga, also are common and suggest a decrease in lake level. Some taxa, such as Anomoeoneis sphaerophora, are indicative of moderate salinity $\left(\sim 0.5-5.0 \mathrm{~g} \mathrm{~L}^{-1}\right)$ (Cumming et al., 1995). In zone 5, the decrease in plankton and correlative increase in benthic taxa, such as Pseudostaurosira brevistriata, Staurosirella pinnata, Staurosira construens, and Fragilaria capucina indicate continued lake-level decline. In the Core 24-A-02 record, epiphytic taxa, such as Achnanthes and Gomphonema, increase toward the top of zone 5, suggesting the expansion of aquatic plants. Zone 6 is somewhat similar to zone 1 in that benthic and epiphytic taxa are abundant, most notably Nitzschia, Fragilaria/Staurosira, and Achnanthes, as well as species characteristic of high alkalinity, such as Epithemia spp., Diploneis pseudovalis, and Rhopolodia spp.

\section{Discussion}

\section{Lake origin}

The most likely mechanism for creation of the Cobb and Wobig basins was blockage of the ancient Niobrara River valley by a dune dam. This blockage allowed up to $55 \mathrm{~m}$ of lacustrine and alluvial sediment to accumulate in the narrow Cobb Basin. Although other possibilities exist for lake formation, they are less likely based on characteristics of the Cobb Basin deposits. The decrease in basin depth from east to west suggests a dune dam at the eastern margin of the basin (Figure 6). The great thickness of the deposits and their location near the rim of the valley seem to preclude that the stream was blocked by a landslide from the valley walls (Loope and Swinehart, 2000). The only evidence of landslides along the Niobrara River occurs to the east, where the Pierre Shale is exposed along the river. Most of these landslide features are much smaller and limited in thickness. The Cobb Basin is too large to be an oxbow lake fill. The ancient Niobrara River at this time was entrenched, and a very large flood would be required to overcome its valley walls and change paths. In addition, the Cobb Basin units are not characteristic oxbow fill/ flood deposits of fine-grained suspended sediment.

Many modern lakes and wetlands in the western Nebraska Sand Hills are a result of dune blockages on drainage systems that run southeastward through the Sand Hills (Loope et al., 1995 and Mason et al., 1997). This model of lake formation suggests that once a dune was established over a streambed, the water table rose behind it, creating a wetland and allowing sediment accumulation behind the dam. Subsequent changes in lake level behind the dam were a product of the balance between groundwater and surface water inflow plus precipitation (inputs) and evaporation and seepage through the dam (outputs). A dune blockage over the Blue Creek paleodrainage has generated over 1,000 lakes and marshes in western Nebraska and resulted in a water table rise of approximately $25 \mathrm{~m}$. Peat and mud seal the dune dam and have produced steady sediment aggradation and the maintenance of a high water table behind the dam (Loope et al., 1995).

\section{Depositional environments}

Cobb Basin and the lake created within it were largely fed by groundwater, because the underlying poorly consolidated sediments of the Ogallala Group (Swinehart and Diffendal, 1998), combined with the highly permeable alluvium on the floor of the channel, would certainly have provided sufficient groundwater infiltration and inflow to maintain the lake. We envision that during precipitation events, surface runoff would deposit additional sediment from the surrounding tributaries and watershed. Depending on lake level, coarse sediment might be transported to the deepest part of the basin or deposited in the upstream portion of the lake. When lake level was high, as in diatom zone 3, much of the coarser clastic input (sand, silt) was probably deposited further upstream (westward) in the basin, where the river flowed into the lake and 


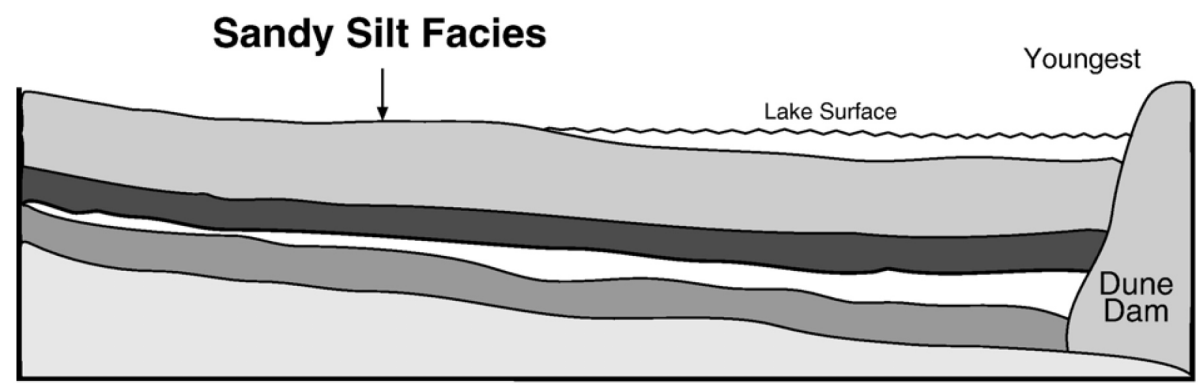

Peat \& Sand Facies

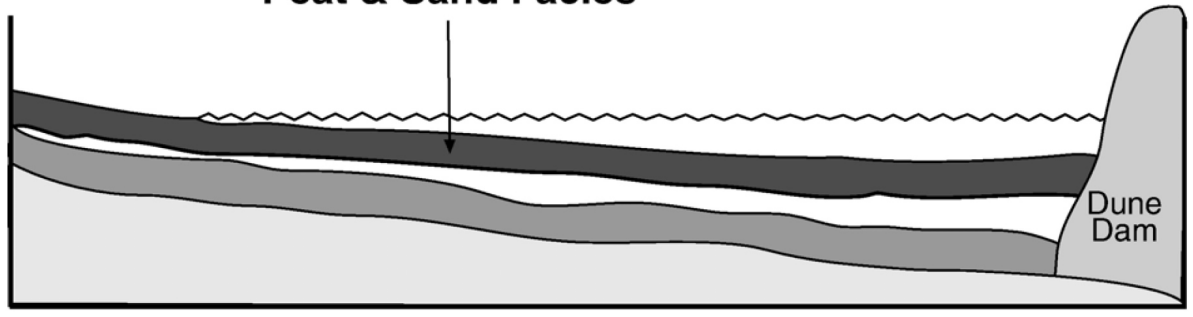

Diatomite Facies
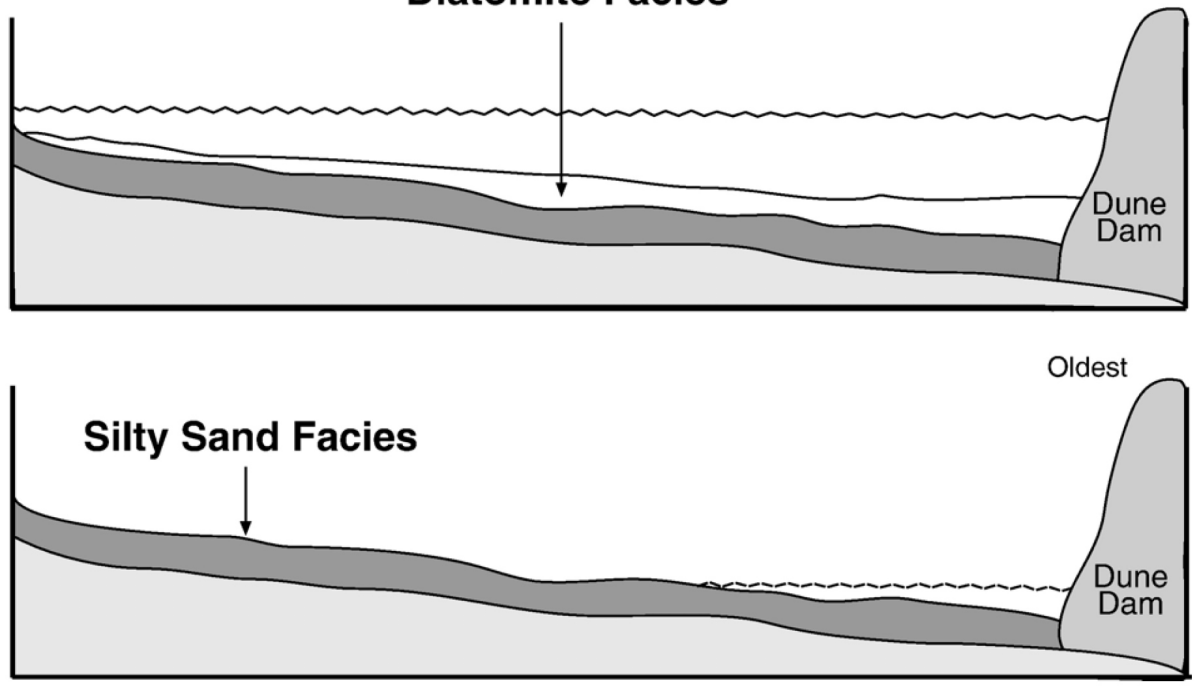

Figure 6. A series of block diagrams showing the reconstructed history of the Cobb Basin from the basin origin to the final stage before breaching of the dune dam. The uppermost white unit is water.

velocity decreased enough for sand and other coarse sediment to drop out of suspension. In the deeper portions of the basin (where the diatom sampling took place), fine materials, such as silt, diatoms, and clay, were deposited.

Precipitation must have been very low in the earliest stages of the Cobb Basin record to allow for dune mobilization and migration across the paleo-drainage. The overlying basal silty sand facies, as well as the upper sandy silt facies (Figure 3), both represent times of reduced precipitation, as indicated by the extensive clastic sediment deposited in the deepest section of the basin.

Lacustrine diatomites form in lakes where clastic input from the surrounding land is low, such that the diatom silica deposition rate greatly exceeds the deposition rate of other sediments (Harwood, 1999). This implies that the Cobb Basin diatomite was either deposited under (1) very arid conditions with little local precipitation and runoff to bring clastic sediment into the basin, (2) when lake level was high enough that the coarser clastic material was deposited in the upstream section of the lake, or (3) during a period when clastic input was limited because the landscape was stable and well vegetated. The diatom species composition (see below) suggests either (or both) of the latter two scenarios. Regional groundwater is high in dissolved silica, which likely enhanced the formation and preservation and of the diatomite.

A peat and sand facies (Figure 3) overlies the diatomite facies and contains more organic material/peat than the underlying diatomite. During the deposition of this unit, local groundwater seepage may have decreased, changing the chemistry and level of the lake. The lake was shallower at this time, probably as a result of decreased regional precipitation, higher evaporation rates, and possibly seepage through the dune dam. 


\section{Limnological environments}

Most of the diatom species in the Cobb Basin deposits (Figure 4) are indicative of relatively freshwater conditions, consistent with a reservoir system fed by fresh groundwater and local precipitation. A series of transitions in the diatom stratigraphy, however, suggest changes in water depth through time. Early in the history of the lake (zone 1), the dominance of epipelic and epiphytic diatoms suggests shallow mud environments with abundant aquatic vegetation. Over time, the lake underwent a progressive increase in depth. The dominant species in zone 2, such as Pseudostaurosira brevistriata, Staurosira construens, and Fragilaria capucina, are not well adapted to shallow highly agitated conditions and prefer deeper littoral environments lakeward of the wave base (Jorgensen, 1948 and Bradbury, 1975). The subsequent increase (zone 3) of a diverse assemblage of eutrophic planktonic diatoms (Stoermer and Yang, 1969 and Cumming et al., 1995) indicates a substantial increase in lake depth. The deposition of the diatomite implies very high algal productivity, consistent with the inference from the species composition (e.g. Stephanodiscus, Cyclostephanos) of high nutrient concentrations.

The upper part of the sequence shows a progressive decline in lake level, as indicated by the decline in planktonic diatoms, which reach very low abundances by zone 5 . In zone 4, the high percentages of Anomoeoneis sphaerophora, $\mathrm{Na}$ vicula oblonga, and Cyclotella meneghiniana are suggestive of slightly higher salinity values (Cumming et al., 1995) than previous and subsequent zones. Zone 5 and zone 6 are similar in species composition to zones 2 and 1, respectively, and are dominated by shallow-water diatoms. The presence of Epithemia, Rhopolodia, Diploneis, and Anomoeoneis in zone 6 indicates that alkalinity was somewhat elevated, although the lake was likely still fresh.

\section{Climate}

The radiocarbon chronology suggests that Paleolake Cobb originated about 45,000 cal yr BP. Although the chronology is poorly constrained above our basal ages (Table 1, Figure 5), we hypothesize based on the other radiocarbon ages that the lake persisted at least 10,000 yr. This would place the basin fill during the latter part of MIS3. During this time, most climate records from the central Great Plains and surrounding areas indicate climate was cool and dry (Bettis et al., 2003). The Cobb Basin record is consistent with this interpretation in the early stages of the record, given that migration of dune sand across the ancestral Niobrara River to form a dune dam is likely only in an arid climate. Thus, the Cobb Basin record provides circumstantial evidence for a period of dune activity and migration during MIS3 prior to $\sim 45,000 \mathrm{yr}$ BP. The persistence of the lake behind the dune dam also implies that precipitation and water level were insufficient to breach the dune dam throughout the history of the lake.

Although the inferred climate was clearly not pluvial, the diatom record indicates that effective moisture increased significantly during the period of deposition of the diatomite. The dominance of planktonic diatom species in zone 3 indicates that lake level was highest during this zone. The high diatom productivity necessary to form a diatomite and the conditions necessary for its subsequent preservation suggest that the lake was fed primarily by silica-rich groundwater during this time. Thus, the increase in lake level suggests increased precipitation within the recharge areas of the Niobrara River drainage basin to the west and in the Cobb Basin region. This elevated precipitation recharged the water table, increased groundwater discharge, and ultimately raised lake level. The dune dam at this time must have been stabilized and effective, with low seepage rates, allowing the lake level to rise behind the dam. The progressive decrease in lake level during the latter stages of the lake's history suggests a subsequent decrease in precipitation, and the presence of diatoms indicative of slightly saline and alkaline waters suggests evaporative concentration of lake waters.

It is tempting to correlate the lake-level cycle from dry to wet to dry to a Bond cycle (sensu Lehman, 1993), each of which persisted for 10,000-15,000 yr. Unfortunately, direct age correlation cannot be made to determine how the precipitation variation evident in this central Great Plains site is linked to North Atlantic climate variability. In the Black Hills immediately to the north of the Nebraska Sand Hills (Serefiddin et al., 2004), a transition from prairie to forest about 45,000 yr BP followed by a return to grassland after 35,000 BP suggests changes in temperature that are approximately contemporaneous with the duration of the paleolake in Cobb Basin. Thus, there is limited regional evidence for an oscillation in climate between 45,000 and 35,000 yr BP, approximately correlative with the interval between Henirich 5 and 4 (Bond et al., 1993). More locally, the Gilman Canyon Formation ( 45,000-23,000 cal yr BP) contains slightly darker horizons, reflecting variations in pedogenic alteration (Johnson et al., in press) associated with intervals of higher precipitation, which may be correlative with the Lake Cobb diatomite deposition. In any case, it is clear from the well-dated alluvial sediments overlying the Cobb Basin that by $\sim 27,000 \mathrm{cal} \mathrm{yr}$ BP the Cobb Basin was filled and occupied by a shallow wide ephemeral river. The inference of aridity in the Cobb Basin at this time is consistent with evidence from the regional loess stratigraphy of a cold dry climate (Madole, 1995 and Muhs et al., 1999). Thus, the inferred period of moderately high precipitation during MIS3, which formed the high lake stage in Cobb Basin, stands in contrast with the arid climate in the central Great Plains during MIS2.

\section{Acknowledgments}

Cody Jacobs assisted with fieldwork, and Dave Loope, Bruce Bailey, and Mike Voorhies provided helpful discussion on the interpretation of the Cobb and Wobig Basin stratigraphy. We thank the Cobb Ranches and the Simmon's Ranch for granting access to their property. Dedicated to J. Platt Bradbury in honor of his pioneering work on the diatom stratigraphy of western North America. 


\section{References}

Alkeinikoff ET AL., 1998 - J. N. Alkeinikoff, D. R. Muhs, and C. M. Fanning, "Isotopic evidence for the sources of Late Wisconsin (Peoria) Loess, Colorado and Nebraska: implications for paleoclimate." In: A. Busacca, Editor, Dust Aerosols, Loess Soils, and Global Change, Washington State University, Pullman, Washington (1998), pp. 124-127.

Bettis ET AL., 2003 - E. A. I. Bettis, J. P. Mason, J. B. Swinehart, X. Miao, P. R. Hanson, R. J. Goble, D. B. Loope, P. M. Jacobs, and H. M. Roberts, "Cenozoic eolian sedimentary systems of the USA mid-continent." In: J.D. Easterbrook, Editor, Quaternary Geology of the United States, INQUA 2003 Field Guide Volume, Desert Research Institute, Reno, Nevada (2003), pp. 195-218.

Bond ET AL., 1993 — G. Bond, W. Broecker, S. Johnsen, J. McManus, L. Labeyrie, J. Jouzel, and G. Bonani, Correlations between climate records from North Atlantic sediments and Greenland ice, Nature 365 (1993), pp. 143-147.

Bradbury, 1975 - J. P. Bradbury, Diatom stratigraphy and human settlement in Minnesota, Special Paper - Geological Society of America 171 (1975), pp. 1-74.

Cumming et AL., 1995 - B. F. Cumming, S. E. Wilson, R. I. Hall, and J. P. Smol, Diatoms from British Columbia (Canada) Lakes and Their Relationship to Salinity, Nutrients, and Other Limnological Variables, Koeltz Scientific Publishers, Stuttgart, Germany (1995).

DansgaArd ET AL., 1993 - W. Dansgaard, S. J. Johnsen, H. B. Clausen, D. Dahl-Jensen, N. S. Gunderstrup, C. U. Hammer, C. S. Hvidberg, J. P. Steffensen, A. E. Sveinbjirnsdottir, J. Jouzel, and G. Bond, Evidence for general instability of past climate from a 250-kyr ice core record, Nature 364 (1993), pp. 218-220.

Dyke and Prest, 1987 - A. S. Dyke and V. K. Prest, Late Wisconsinan and Holocene history of the Laurentide Ice Sheet, Geographie physique et Quaternaire 41 (1987), pp. 237-264.

Forman and Pierson, 2002 - S. L. Forman and J. Pierson, Late Pleistocene luminescence chronology of loess deposition in the Missouri and Mississippi river valleys, Palaeogeography, Palaeoclimatology, Palaeoecology 186 (2002), pp. 25-46.

Forman Et AL., 1992 - S. L. Forman, E. A. I. Bettis, T. Kemmis, and B. B. Miller, Chronological evidence for multiple periods of loess deposition during the late Pleistocene in the Missouri and Mississippi River Valleys, U.S.: implications for the activity of the Laurentide Ice Sheet, Palaeogeography, Palaeoclimatology, Palaeoecology 93 (1992), pp. 71-83.

FredLund, 1955 - G. Fredlund, Late Quaternary pollen record from Cheyenne Bottoms, Kansas, Quaternary Research 43 (1955), pp. 67-79.

Fritz ET AL., 1993 - S. C. Fritz, S. Juggins, and R. W. Battarbee, Diatom assemblages and ionic characterization of lakes of the Northern Great Plains, North America: a tool for reconstructing past salinity and climate fluctuations, Canadian Journal of Fisheries and Aquatic Sciences 50 (1993), pp. 1844-1856.

Goble ET AL., 2004 - R. J. Goble, J. A. Mason, D. B. Loope, and J. B. Swinehart, Optical and radiocarbon ages of stacked paleosols and dune sands in the Nebraska Sand Hills, USA, Quaternary Science Reviews 23 (2004), pp. 1173-1182.

Harwood, 1999 — D. M. Harwood, "Diatomite." In: E. F. Stoermer and J. P. Smol, Editors, The Diatoms: Applications for the Environmental and Earth Sciences, Cambridge University Press, Cambridge, UK (1999), pp. 436-443.

Johnson ET AL., IN PRESS - W. C. Johnson, K. L. Willey, J. A. Mason, and D. W. May. Stratigraphy and environmental reconstruction at the Middle Wisconsinan Gilman Canyon Formation Type Locality, Buzzard's Roost, Southwestern Nebraska, USA. Quaternary Research, in press.

Jorgensen, 1948 - E. K. Jorgensen, Diatom communities in Danish lakes and ponds, Dansk Videnskabernes Selskab, Biologiske Skrifter, Kongelige 5 (1948), pp. 1-140.

JugGins, 2003 - S. Juggins, C2 User Guide: Software for Ecological and Palaeoecological Data Analysis and Visualization, University of Newcastle, Newcastle upon Tyne, UK (2003).
LARSON, 2001 - Larson, C., (2001). "Provenance, distribution, and Sand Hills dune sand source potential Connely Flat Beds, (Latest Wisconsin), Niobrara River, Ainsworth to Merriman, Nebraska." Unpublished M.S. thesis, University of Nebraska.

LeHMAN, 1993 - S. Lehman, Ice sheets, wayward winds and sea change, Nature 365 (1993), pp. 108-110.

Loope and Swinehart, 2000 - D. B. Loope and J. B. Swinehart, Thinking like a dune field: geologic history in the Nebraska Sand Hills, Great Plains Research 10 (2000), pp. 5-35.

Loope ET AL., 1995 - D. B. Loope, J. B. Swinehart, and J. P. Mason, Dunedammed paleovalleys of the Nebraska Sand Hills: intrinsic versus climatic controls on the accumulation of lake and marsh sediments, Geological Society of America Bulletin 107 (1995), pp. 396-406.

MaAt and Johnson, 1996 - P. B. Maat and W. C. Johnson, Thermoluminescence and new 14C age estimates for late Quaternary loesses in southwestern Nebraska, Geomorphology 17 (1996), pp. 115-128.

Madole, 1995 - R. F. Madole, Spatial and temporal patterns of late Quaternary eolian deposition, Eastern Colorado, U.S.A., Quaternary Science Reviews 14 (1995), pp. 155-177.

Mason, 2001 - J. A. Mason, Transport direction of Peoria Loess in Nebraska and implications for loess sources on the Central Great Plains, Quaternary Research 56 (2001), pp. 79-86.

Mason ET AL., 1997 — J. P. Mason, J. B. Swinehart, and D. B. Loope, Holocene history of lacustrine and marsh sediments in a dune-blocked drainage, southwestern Nebraska Sand Hills, USA, Journal of Paleolimnology 17 (1997), pp. 67-83.

Mason et AL., 2004 - J. A. Mason, J. B. Swinehart, R. J. Goble, and D. B. Loope, Late-Holocene dune activity linked to hydrological drought, Nebraska Sand Hills, USA, Holocene 14 (2004), pp. 209-217.

Muhs ET AL., 1999 — D. R. Muhs, J. B. Swinehart, D. B. Loope, J. N. Aleinikoff, and J. Been, "200,000 years of climate change recorded in eolian sediments of the High Plains of eastern Colorado and western Nebraska." In: D.R. Lageson, A.P. Lester and B.D. Trudgill, Editors, Colorado and Adjacent Areas: Geological Society of America Field Guide 1, Geological Society of America, Boulder, CO (1999), pp. 71-91.

Muhs ET AL., 2000 - D. R. Muhs, J. B. Swinehart, D. B. Loope, J. Been, S. A. Mahan, and C. A. Bush, Geochemical evidence for an eolian sand dam across the North and South Platte Rivers in Nebraska, Quaternary Research 53 (2000), pp. 214-222.

Roberts et AL., 2003 - H. M. Roberts, D. R. Muhs, A. G. Wintle, G. A. T. Duller, and E. A. Bettis III, Unprecedented last-glacial mass accumulation rates determined by luminescence dating of loess from western Nebraska, Quaternary Research 59 (2003), pp. 411-419.

Serefiddin ET AL., 2004 - F. Serefiddin, H.P. Schwarcz, D. C. Ford, and S. Baldwin, Late Pleistocene paleoclimate in the Black Hills of South Dakota from isotope records in speleothems, Palaeogeography, Palaeoclimatology, Palaeoecology 203 (2004), pp. 1-17.

Stoermer and Yang, 1969 - E. F. Stoermer and J. J. Yang, Plankton Diatom Assemblages in Lake Michigan. Great Lakes Research Division, The University of Michigan (1969).

Swinehart and Diffendal, 1998 - J. B. Swinehart and R. F. Diffendal, "Geology of the pre-dune strata." In: A. S. Bleed and C. A. Flowerday, Editors, An Atlas of the Sand Hills, University of Nebraska, Lincoln, NE (1998), pp. 29-56.

Swinehart ET AL., 1996 - J. B. Swinehart, P. E. Helland, and B. E. Bailey, Thick Pleistocene (40 ka) lake sediments discovered in ancestral Niobrara River valley, north-central Nebraska, Abstracts - Geological Society of America 28 (1996), p. 304.

Wilhite and HubBard, 1998 - D. A. Wilhite and K. G. Hubbard, "Climate." In: A. S. Bleed and C. A. Flowerday, Editors, An Atlas of the Sand Hills, University of Nebraska, Lincoln (1998), pp. 17-28. 